\title{
Evaluating good-practice cases for river restoration across Europe: context, methodological framework, selected results and recommendations
}

\author{
S. Muhar $\cdot$ K. Januschke $\cdot$ J. Kail $\cdot$ \\ M. Poppe $\cdot$ S. Schmutz $\cdot$ D. Hering $\cdot$ A. D. Buijse
}

Received: 29 April 2015/Revised: 7 November 2015/Accepted: 10 December 2015/Published online: 27 January 2016

(C) The Author(s) 2016. This article is published with open access at Springerlink.com

\begin{abstract}
This introductory paper presents 20 river restoration cases throughout Europe that were investigated in the EU-funded research project REFORM. In the following, this special issue provides seven specific papers that highlight and discuss the effects of restoration on the investigated river-floodplain systems. Additionally, restoration success was estimated from a socio-economic perspective. The first part of this paper presents the overall study concept and the general sampling design of the field investigations. Each study site was examined with the same array of methods, covering habitat composition in the river and its floodplain, three aquatic and two floodplain-related organism groups, as well as food web composition and
\end{abstract}

Guest editors: Jochem Kail, Brendan G. McKie,

Piet F. M. Verdonschot \& Daniel Hering / Effects of hydromorphological river restoration

S. Muhar $(\bowtie) \cdot$ M. Poppe $\cdot$ S. Schmutz

Institute of Hydrobiology and Aquatic Ecosystem

Management, University of Natural Resources and Life

Sciences, Max-Emanuel-Strasse 17, 1180 Vienna, Austria

e-mail: susanne.muhar@boku.ac.at

K. Januschke · J. Kail · D. Hering

Department of Aquatic Ecology, Faculty of Biology, University of Duisburg-Essen, Universitaetsstr. 5, 45141 Essen, Germany

A. D. Buijse

Department of Freshwater Ecology \& Water Quality, DELTARES, Princetonlaan 6, 3584 CB Utrecht, The Netherlands "aquatic terrestrial" interactions as reflected by stable isotopes. An overview of the rivers and the study sites summarizes main attributes of all investigated sites, with emphasis on the large-scale restoration projects. Some of the projects represent the "state of the art" restoration approaches for two major European river types: gravel-bed mountain rivers and sand-bed lowland rivers. Concluding, restoration efforts had positive effects even in the small restoration projects investigated but did not increase with project size. No "single best" measure could be identified, but river widening generally had a larger effect compared to other restoration measures.

Keywords River restoration - Assessment methods . Response variables $\cdot$ Restoration effect

\section{Introduction}

Following a long period of extensive human uses and impacts on riverine systems, the implementation of the European Water Framework Directive (WF-D; 2000/ 60/EG) introduced a new phase of managing European rivers in the EU member states. The legal obligations to maintain or re-establish at least good ecological status of all surface waters led to increased hydromorphological restoration activities. However, research on the ecological and socio-economic impacts of hydromorphological alterations and 
restoration measures, and assessment of the effectiveness of different restoration techniques remain limited. The EU-funded research project "REFORM" (http:// www.reformrivers.eu/) is targeted towards developing guidance and tools to make river restoration and mitigation measures more cost effective. The papers presented in this special issue of Hydrobiologia originate from novel field studies within REFORM in which we investigated the effects of hydromorphological restoration measures. We specifically addressed three issues (Fig. 1) further described in the following: (i) the use of a standardized sampling and study design, (ii) the effects of restoration by considering a broad range of response variables, and (iii) factors (especially factors of spatial scale) potentially influencing restoration effects.

(i) Several studies already investigated the effect of restoration on hydromorphology and biota but reported contrasting results. Some studies showed that the ecological effect of river restoration projects was small even if local river morphology and habitat conditions were substantially improved (Lepori et al., 2005; Jähnig et al., 2010; Palmer et al., 2010). In contrast, other studies found a significant positive effect of river restoration on specific organism groups (Lorenz et al., 2012; Schmutz et al., 2014). This discrepancy is probably partly due to real differences in the effectiveness of the restoration measures applied and other catchment, river, and project characteristics, which either enhance or constrain restoration effect (see, e.g. Kail et al., 2015). Other authors (e.g. Roni et al., 2008), however, explain this variance with large methodological differences in respect to monitoring design, field sampling, and data analysis. These differences limit the comparability of results. Using a standardized monitoring and sampling design as well as data analysis yields a harmonized dataset and might contribute to a better prediction of restoration effects.

(ii) Besides the limitations due to the high variability, it is presently difficult to draw general conclusions on the effect of restoration on biota. This is because most studies were restricted to one or few organism groups, mainly to fish and invertebrates (Lepori et al., 2005; Jähnig et al., 2010; Miller et al., 2010; Schmutz et al., 2014). A few studies were conducted on the effect of restoration on macrophytes (e.g. Lorenz et al., 2012) and ground beetles (Januschke et al., 2011), but comparative studies on several organism groups are rare (Jähnig et al., 2009; Januschke et al., 2014; Kail et al., 2015). Studies
Fig. 1 Conceptual scheme of the REFORM case study assessment

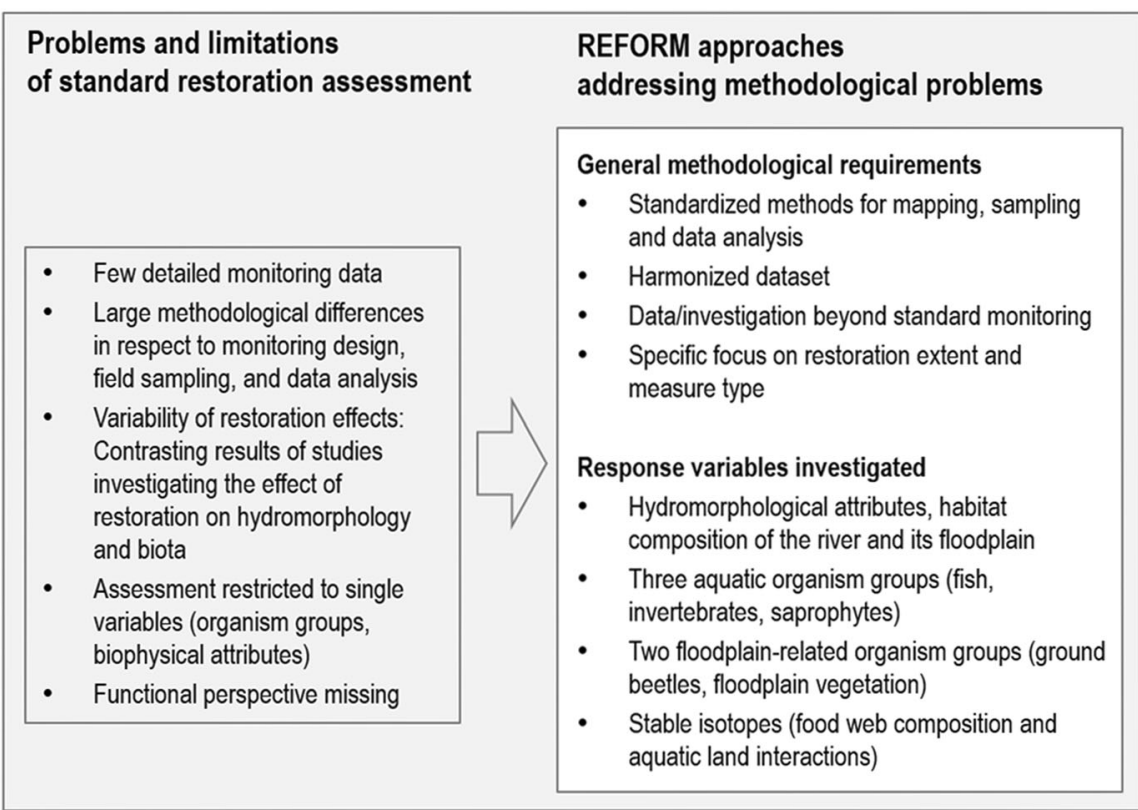


combining aquatic, semi-terrestrial, and terrestrial biota are missing almost entirely (but see Jähnig et al., 2009; Januschke et al., 2014, Nilsson et al., 2015). Therefore, we investigated a broad range of response variables to draw conclusions on the effect of restoration on biota in general. This included habitat composition in the river and its floodplain, three aquatic organism groups, two floodplain-inhabiting organism groups, as well as food web composition and aquatic-land interactions as reflected by stable isotopes.

(iii) In earlier studies, a variety of reasons for limited biotic effects of morphological restoration measures have been suggested: Stressors acting at larger scales such as water quality, especially those associated with intensive land use and hydrological alterations in the catchment (Palmer et al., 2010; Lorenz \& Feld, 2013; Sundermann et al., 2013), might constrain restoration effects. Moreover, this might be caused by the inadequate restoration of hydromorphological processes (Jähnig et al., 2009), minor changes in relevant microhabitats (Lepori et al., 2005), and a limited re-colonization potential due to a lack of source populations and a large number of migration barriers (Stoll et al., 2014; Tonkin et al., 2014).

Moreover, there is overwhelming evidence that stressors acting at larger spatial scales (catchment, subcatchment, sections with a length of several kilometres) influence aquatic assemblage composition (Kail \& Hering, 2009; Lorenz \& Feld, 2013; Marzin et al., 2013; Wahl et al., 2013).

Many of these parameters, which potentially limit the effects of habitat enhancement, may be mitigated in large restoration projects in which restored sections are relatively long and/or restoration actions have been intense. Accordingly, restoration effect possibly depends on restoration extent. Hydromorphological processes are strongly linked to the issue of spatial scale, including the formation of meanders and braided patterns and of riffle-pool sequences (Richards et al., 2002). Similarly, water quality parameters may differ between short and long restored river sections: the effect of riparian forests on water temperature depends on the length of the shaded river section (Kiffney et al.,
2003); self-purification depends on the length of a section with near-natural morphology. Assuming similar large-scale pressures, short restored sections are likely to be more strongly impacted by stressors acting at the catchment scale, e.g. fine sediment entry. Finally, the effect of natural channel features such as large wood or boulders on the habitat conditions and biota largely depends on the amount present (Fausch \& Northcote, 1992). A strong correlation between the restoration extent and the biological effects can therefore be assumed. Therefore, we compiled additional data on factors potentially constraining or enhancing the effect of restoration to identify conditions that favour restoration success and designed the study to focus on the effect of restoration extent.

This introductory paper of the special issue (i) presents the general study design, (ii) gives methodological information on the study sites, the criteria used for selection, and the sampling design, (iii) exemplarily highlights the main findings and introduces the individual papers of the special issue.

\section{General study design}

Paired comparison of large versus small restoration projects

Ten large and ten similar but small restoration projects were investigated to address the role of restoration extent (size and intensity of restoration measures) for river restoration effects. The large restoration projects (R1; median length $1.6 \mathrm{~km}$ ) represented good-practice examples of medium-sized lowland or mountain rivers. The small restoration projects ( $\mathrm{R} 2$; median length $0.5 \mathrm{~km}$ ) were located in rivers of comparable size and character, but their restoration stretch was shorter and their restoration intensity (in terms of restoration effort, and quality parameters addressed, see also Poppe et al., 2015) lower.

For each small and large project, one sample section was selected in the downstream part of the restored river section. Additionally, a non-restored section upstream of the restored section (D1, D2) was selected (Fig. 2), which is still impacted by the same pressures that were once compromising the now restored river sections. Comparing each restored river section with the nearby still degraded river section enabled quantifying the restoration effect. 
Fig. 2 General study design of the paired restored sections (R1,

$\mathrm{R} 2$...restoration projects, D1, D2...degraded control sections)

\section{Large restoration project $\mathrm{R} 1 \quad$ Small restoration project $\mathrm{R} 2$}

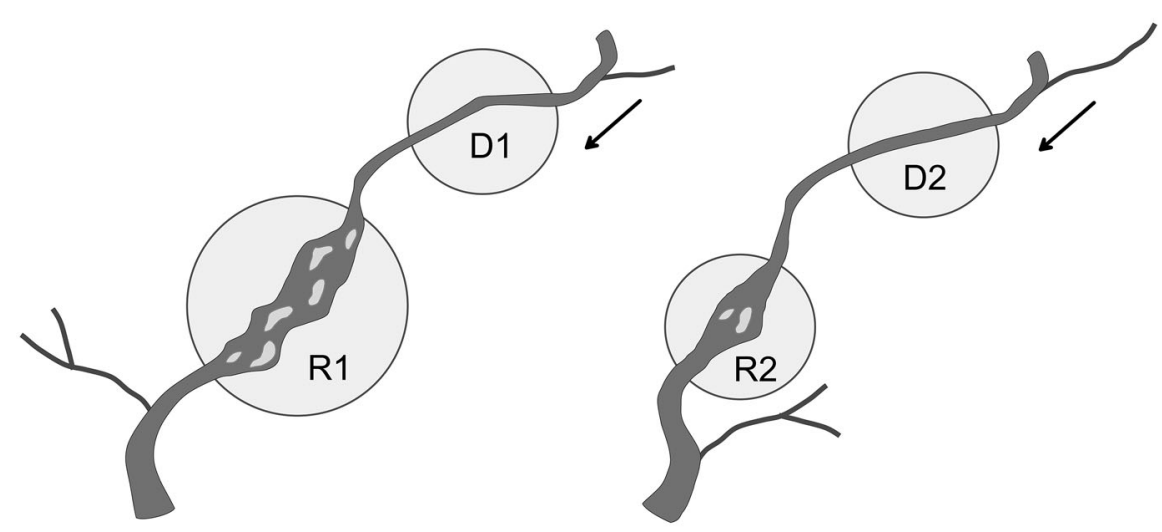

The case-studies mainly covered small to mediumsized rivers in Northern, Eastern and Central Europe, reflecting the relatively long tradition in river restoration in these regions. The restoration techniques mainly included planform measures like remeandering and widening as well as in-channel measures like the removal of bank fixation and addition of large wood and boulders.

The 40 investigated sections ( 20 restored, 20 nonrestored) were sampled for the following response variables: hydromorphological variables, three aquatic organism groups (fish, benthic invertebrates, aquatic macrophytes), two floodplain organism groups (ground beetles and floodplain vegetation) and stable isotopes.

Although the restored sections were comparable in terms of river size, catchment land use and altitude and were selected to differ only in terms of restoration extent, there were inevitable differences between regions. To account for these regional differences, we limited the comparisons of small and large projects to the corresponding pairs of large and small projects and their respective degraded control sections. For the comparison between regions, we used the pairwise difference of corresponding large and small projects (R1 minus R2).

\section{Quantifying restoration effects}

The effect of restoration was quantified using different variables in different units. This included ordinal scaled assessment scores for the hydromorphological state, biological metrics (e.g. richness, diversity, number of sensitive taxa) for assessing the biological state and units to quantify species abundance (e.g. number of fish individuals, abundance classes of invertebrates).

For detailed analysis of each response variable, we used two different approaches:

- We quantified the effect of restoration by subtracting values of the degraded sections from the restored sections. This yields positive values denoting an increase and negative values denoting a decrease of the variable. While this effect size is easy to interpret, it has the disadvantage that different variables or variables measured in different units cannot be compared.

- The response ratio of Osenberg et al. (1997), which assumes an exponential model by using a logarithmic function, has the advantage that it is dimensionless. This enabled comparing the effect of restoration on different variables describing the hydromorphological, biological and isotope conditions.

\section{Study sites and sampling design}

Study sites

The ten pairs of one large and a similar but small restoration project were selected to cover two main river types (gravel-bed mountain rivers and sand-bed 
lowland rivers) and a wide range of different hydromorphological restoration measures. Moreover, we considered the availability of already existing monitoring data on the rivers and their catchments and the accessibility in the field as additional criteria for study site selection. The selected study sites/restoration projects were located in Northern, Eastern and Central Europe (Fig. 3): sites in gravel-bed rivers were located in the Alps (Drau, Enns, Thur, Töss), the Hungarian lowlands (Becva, Morava), the Central Highlands (Ruhr, Lahn) and the Fenno-scandian shield (Vääräjoki, Kuivajoki, Emån, Mörrumsån); sites in sandbed rivers were located in the Central (Skjern, Stora, Lippe, Spree, Regge,Warta), Western (Dommel) and Eastern plains (Narew).

The ten pairs of large and small restoration projects were similar in respect to upstream catchment size, ranging from 339 to $6275 \mathrm{~km}^{2}$, but there were regional differences in respect to other site characteristics which allowed us to investigate their effect on restoration outcomes (e.g. percentage cover of agricultural land use ranged from $1 \%$ to $80 \%$, see summary of site characteristics in Tables 1 and 2). The large and small restoration projects within pairs and regions were selected to be similar in terms of catchment and river characteristics (e.g. river size hydraulic conditions, land use) and hence, were comparable. As the degraded control reaches were always located close to the restored reaches, the differences in altitude, slope, discharge and catchment land cover were minor.

The main restoration measures applied in the gravel-bed rivers were widening of the cross section, removal of bed and bank fixation and flattening river banks, which created extensive aquatic-terrestrial transition zones. Due to river bed widening and the rising of the river bottom, former side arms as well as tributaries had been re-connected or secondary channels and water bodies had been revived. Additionally, instream structures like large wood and boulders were added. In the lowland rivers, remeandering and reconnecting side arms were the most prominent measures. Groundwater levels were raised for restoring wetlands and instream measures were implemented to enhance spawning habitats for fish. Moreover, many restoration projects aimed to initiate natural processes like natural morphodynamics instead of being mere form-based approaches that usually try to create or add channel features.

In the following, two of the restoration projects are described in more detail as typical examples for the gravel-bed and sand-bed study sites. Detailed information on all other restoration projects is available at http://reformrivers.eu/system/files/4.3\%20Effects\% 20of\%20large-\%20and\%20small-scale\%20restoration. pdf.

One of the gravel-bed study sites is located in the Drau River in Austria, where a large restoration project is situated in the western part of the federal province Carinthia. In the years 2002 to 2003, several restoration measures were implemented over a total length of $1.9 \mathrm{~km}$ (Fig. $4 \mathrm{a}, \mathrm{b}$ ). These included the removal of bank fixation, widening of the river bed, creation of a secondary channel and reconnecting former side arms to the river. Moreover, a new floodplain forest was established on formerly agricultural land (Mandler et al., 2004). The restoration site is part of a large Natura 2000 area. Therefore, management requirements according to the Habitats Directive lead to complementary restoration measures for the river and the adjacent floodplains.

One of the sand-bed study sites is located in the Narew River situated downstream of the Narew National Park (Fig. 5a, b). At this point, the upper catchment comprises about $3680 \mathrm{~km}^{2}$. The mean discharge near the site is $16.9 \mathrm{~m}^{3} / \mathrm{s}$. In this section, the Narew is a 2nd-order stream and assigned to the bream fish region.

In 1995, it was decided to restore the degraded stretch adjacent to the National Park. Over a length of $9 \mathrm{~km}$, several restoration measures were implemented to bring back a natural value of the river valley and to restore the naturally anastomosing river network. Former side channels were re-connected by removing sediment and vegetation accumulations.

Sampling design

All ecologically degraded sections, except one, were located upstream of the corresponding restored sections and at a sufficient distance (mean $4.0 \mathrm{~km}$ ) to prevent mutual interferences. Within each section 


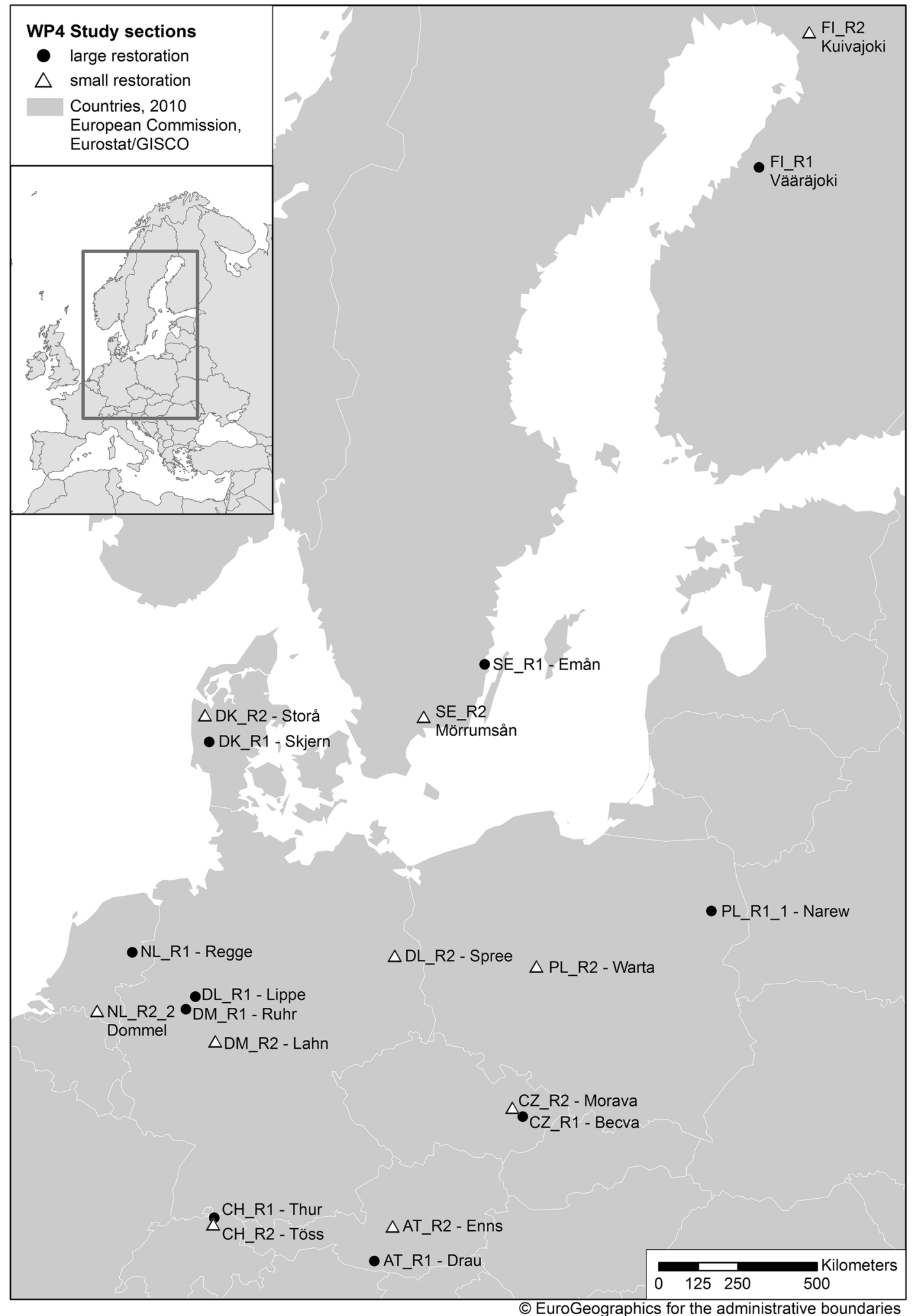


4Fig. 3 Location of the large (R1) and small (R2) restoration projects. Abbreviations consist of the country code, restoration extent code and river name

(degraded and restored), a representative sampling reach was selected. In the restored sections, this reach was located in the downstream part to consider potential mitigating effects of restoration extent. The lengths of the sampling reaches depended on the wetted channel width and the respective response variable. Sampling reaches were 200-500 m long for recording hydromorphology with the transect methods, sampling of ground beetles, floodplain vegetation and stable isotopes (Table 3). For macroinvertebrates and macrophytes, the length of sample reaches was $200 \mathrm{~m}$ irrespective of the wetted channel width. The lateral boundaries of the sampling areas and the sampling seasons differed with regard to the response variables (Table 4).

\section{Selected results and recommendations}

The 20 restoration projects investigated in this study represent good-practice examples in Northern, Eastern and Central Europe. They partly reflect the relatively long tradition in river restoration in these regions. They comprise well-known "standard" types of restoration measures, e.g. creation of instream structures, flow enhancement, remeandering and sidechannel reconnection as well as river widening which mainly involves the removal of bank enforcement and the design of secondary channels which at the same time initializes morphodynamic processes and enables higher diversity of flow velocities and depths.

As rivers or projects from Western or Southern Europe are not included in our study, the transferability of the results is best for mid-sized rivers in these regions. However, the twenty catchments located in nine European countries also showed regional differences (e.g. in terms of dominant substrate type) and differed in respect to the main restoration measures implemented respectively their specific spatial setting. It also needs to be considered that good-practice projects selected from the regions with a long tradition in river restoration were still relatively small scale (e.g. only short restored river reaches compared to the length of the whole degraded river network). Therefore, general conclusions are limited and have to be drawn very carefully, considering these regional differences and other river characteristics. Nevertheless, based on the findings of in total 7 disciplinespecific investigations, the following conclusions and recommendations can be drawn.

First, future projects probably have to be larger to show larger effects. In REFORM, we expected higher restoration effects in larger projects since longer reaches might better mitigate the influence of largescale pressures like fine sediment input and provide a minimum area for hydromorphological processes to act and viable populations to establish. Restoration had positive effects even in the small restoration projects investigated, but the effects were not larger in larger projects and did not increase with project size, except for small rheophilic fish, which revealed stronger responses to sites with restoration length $>1.95 \mathrm{~km}$ than shorter stretches. Most probably, even the largest projects investigated in our study were still too small to show major effects on several response variables. Studies including larger projects indeed found that restoration has higher effects in larger projects (e.g. Muhar et al., 2007; Schmutz et al., 2014).

Second, there was no "single best" measure but widening generally had a larger effect compared to other restoration measures. For example, (i) river widening had a higher effect on macro- and mesoscale habitat diversity compared to remeandering and instream measures (see Poppe et al., 2015), (ii) the effect of restoration on ground beetle richness was especially high in widening projects (see Januschke \& Verdonschot, 2015), (iii) widening had significant effects on macrophytes (in contrast to other restoration measures), with an increase of richness and diversity of submerged species and a decrease of the proportion of competitive species (see Ecke et al., 2015), and (iv) widening had the strongest effects of all project characteristics investigated, particularly on the diversity and composition of species traits favoured by increases in physical disturbance (e.g. flooding) and 


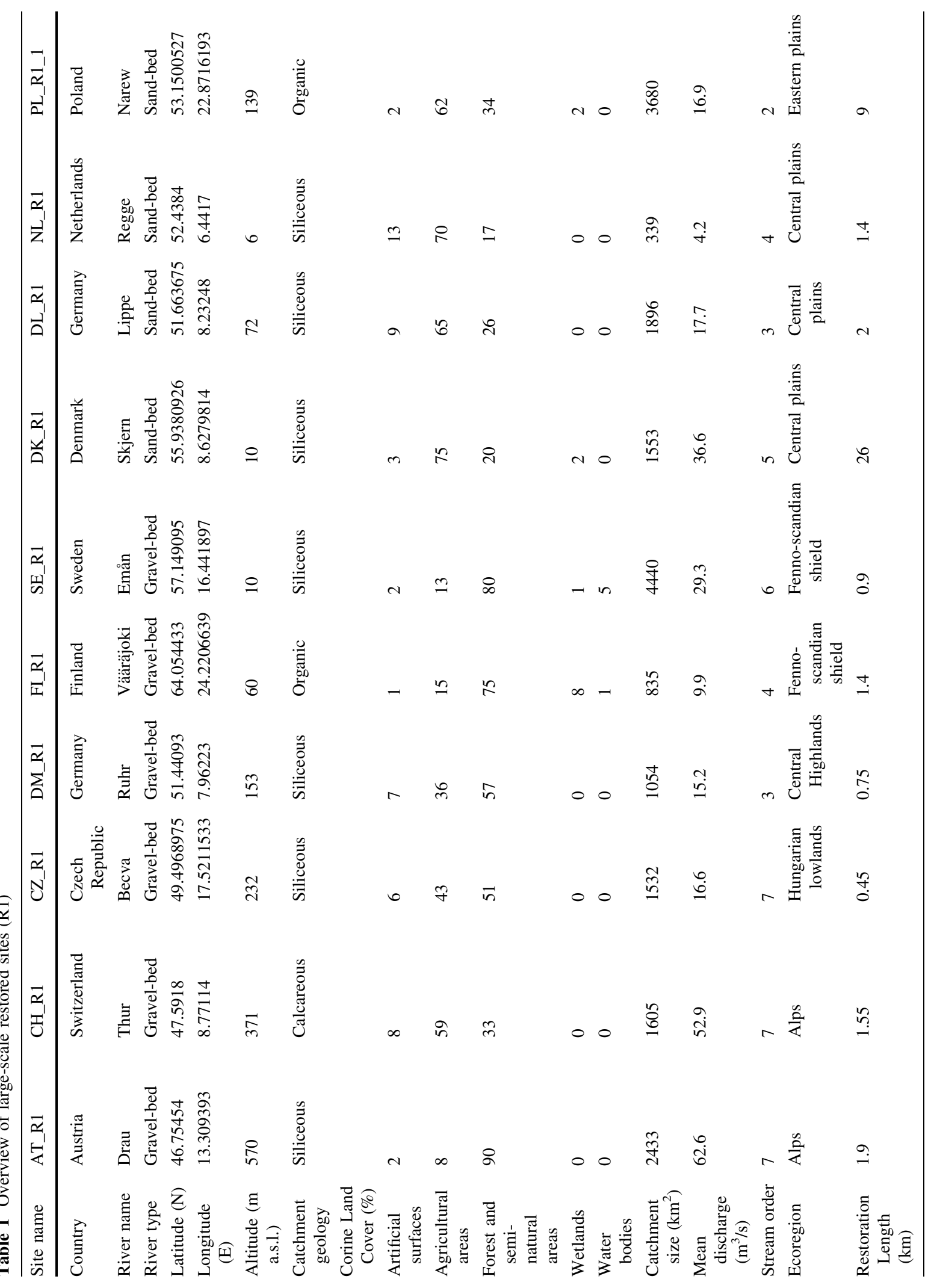




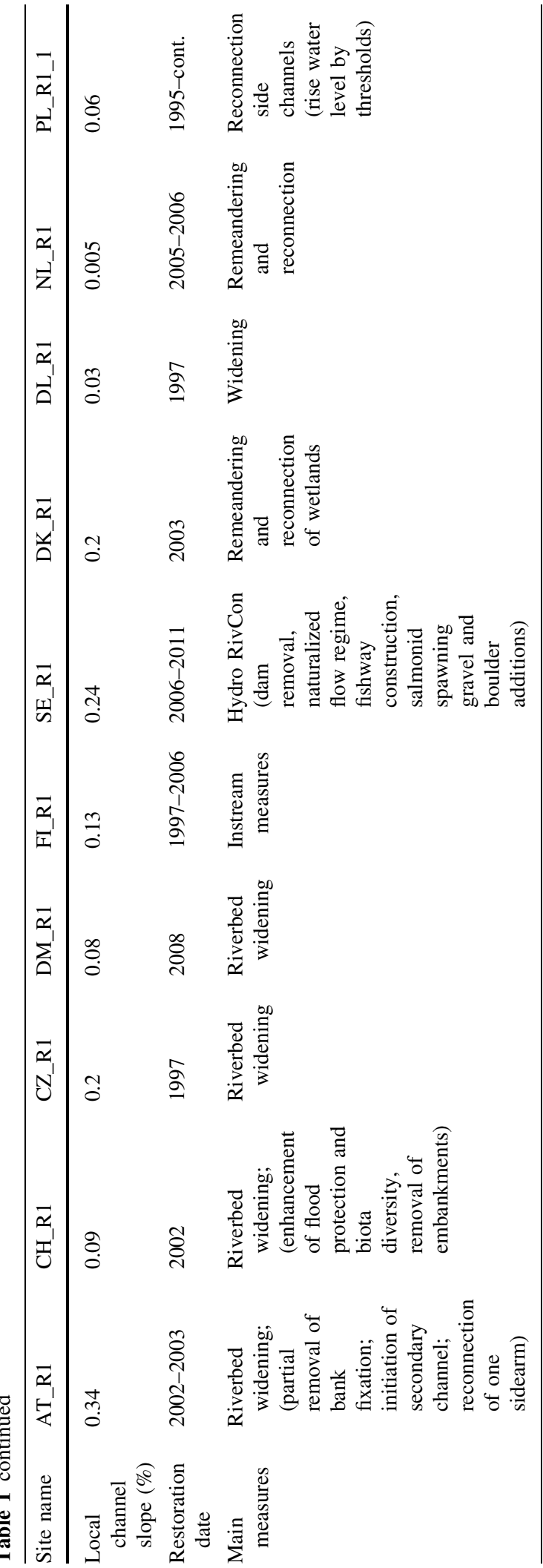

open habitat patch availability (e.g. plant growth form, life strategy and life span) (see Göthe et al., 2015). These results support similar findings of other studies which found high effects of widening projects on ground beetles (Januschke et al., 2014) and macrophytes (Kail et al., 2015). Moreover, these results are consistent with studies showing that terrestrial and semi-aquatic organism groups like floodplain vegetation and ground beetles as well as macrophytes benefit most from planform measures and aquatic groups like fish and invertebrates from instream measures (Jähnig et al., 2009; Januschke et al., 2009; Miller et al., 2010; Lorenz et al., 2012; Haase et al., 2013; Kail et al., 2015). This seems reasonable since the planform measures usually result in pioneer habitats like bare riparian areas and bare gravel bars, reduce flow velocity and water depth, restored reaches are often sparsely shaded in the beginning and hence favour pioneer species in the riparian area and macrophytes in the aquatic zone in the first years. In contrast, pure instream measures like the addition of boulders and large wood or riffle creation mainly enhance aquatic habitats. However, restoration projects usually do not apply single measures but a set of different measures. Moreover, other catchment, river, and project characteristics were co-correlated with restoration effects generally being higher in widening projects located in lower-mountain gravel-bed rivers with a relatively minor land use pressure compared to other projects in lowland sand-bed rivers in agricultural catchments (e.g. widening projects are mainly conducted in gravel-bed rivers with relatively low land use pressure). Therefore, it was difficult to disentangle the effects and to quantify the contribution of specific measure types and the influence of the catchment and river characteristics on restoration outcomes. Further investigations are needed and results must be interpreted with care.

Third, our results indicate that it is crucial to restore specific habitats which are of special importance or presently limiting colonization at spatial scales relevant for biota and not necessarily to increase mere habitat diversity. For example, ground beetle richness did mainly depend on the presence of sparsely vegetated river banks but not on its coverage, i.e. even small patches may already have a positive effect (see Januschke \& Verdonschot, 2015). Moreover, macroinvertebrate richness depended on microhabitat diversity (see Verdonschot et al., 2015). Since 


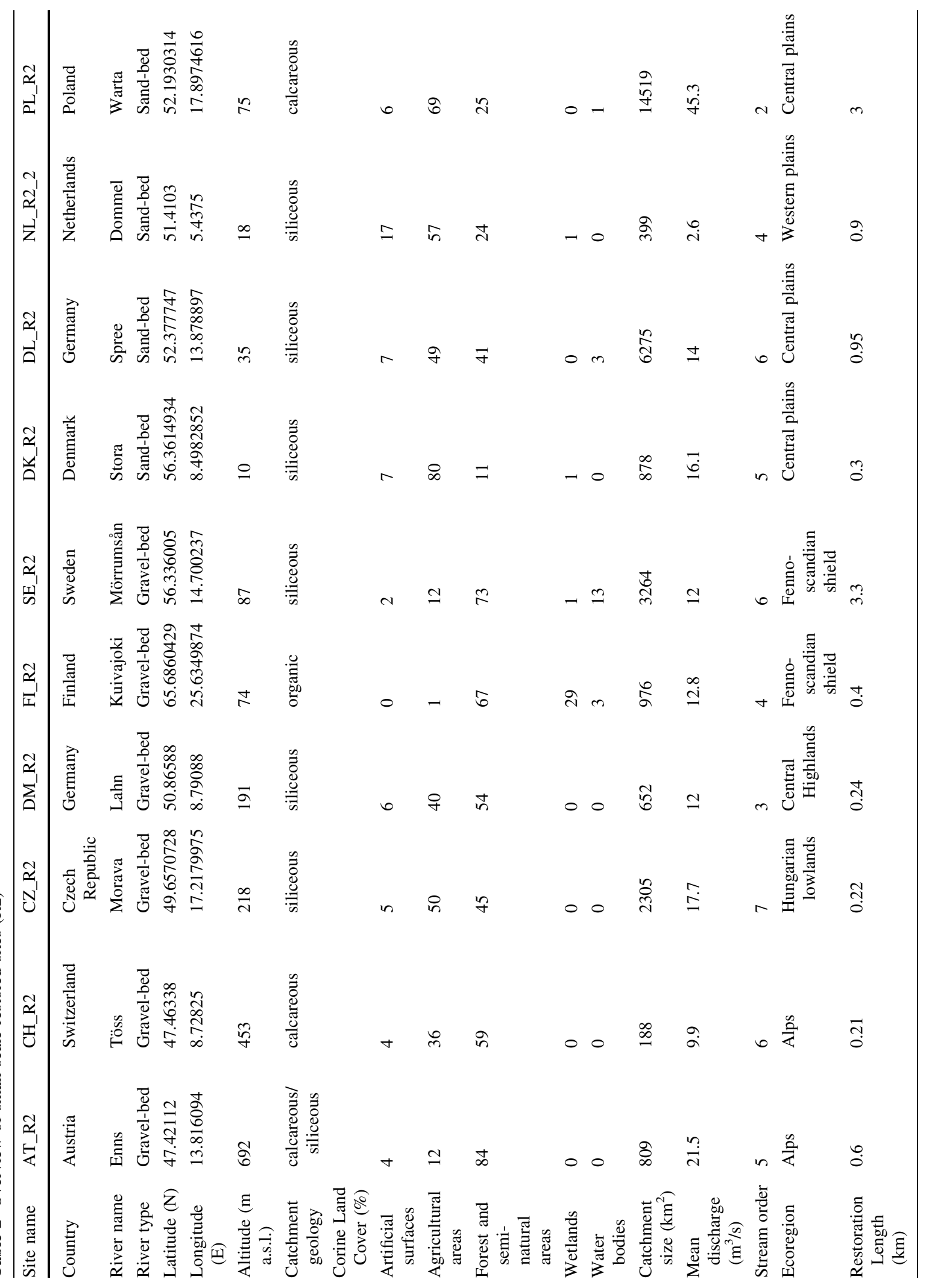




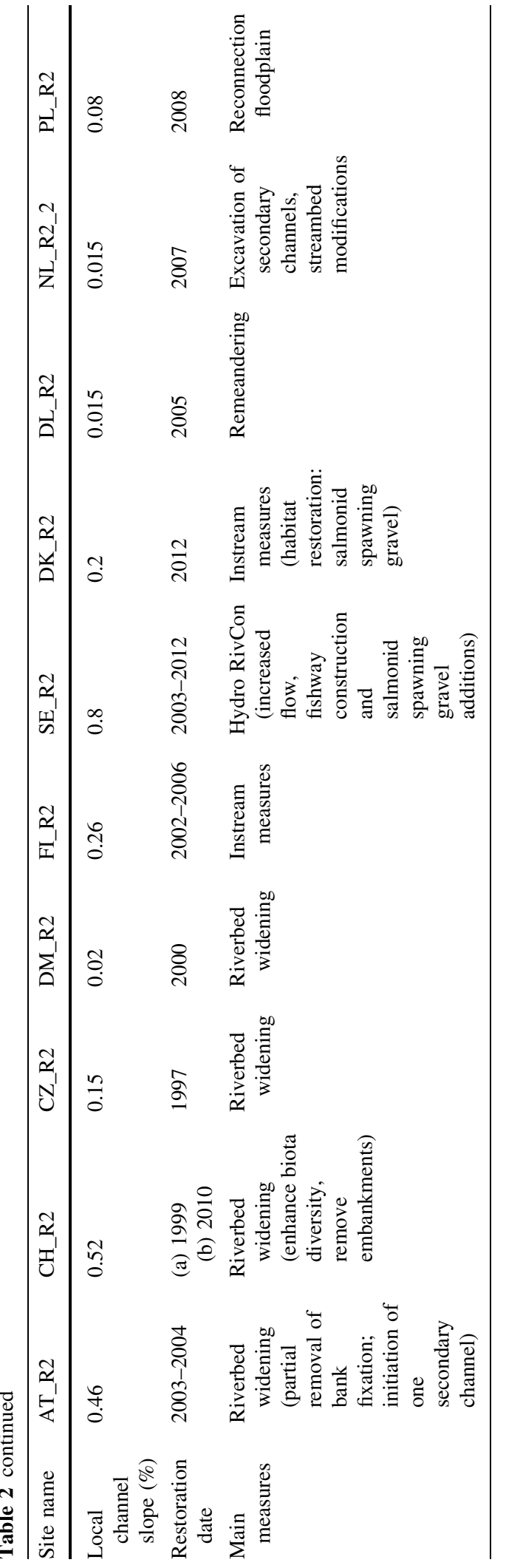

restoration projects had no significant effect on microhabitat diversity (see Poppe et al., 2015), this may at least partly explain the missing effect of restoration on macroinvertebrate richness and diversity (see Verdonschot et al., 2015). These results indicate that although projects restoring river planform by widening or remeandering might increase macro- and mesoscale habitat conditions and hence are visually appealing, they often fail at increasing microhabitat diversity relevant for organism groups like macroinvertebrates.

Fourth, the effects of river restoration projects should be assessed in a more holistic way, addressing the river and its floodplain as a functional unit since they are closely linked and cannot be considered separately, as shown by the increased resource breadth for macroinvertebrates, probably due to the enhanced exchange and input of allochthonous, terrestrial carbon resources (see Kupilas et al., 2015). Furthermore, our findings suggest that not all organism groups benefit from restoration to the same extent. In the 20 restoration projects investigated in REFORM, the effect of restoration on richness and diversity was higher for terrestrial and semi-aquatic compared to aquatic organism groups. Restoration had no or only little effect on species richness or diversity of macroinvertebrates and fish (see Verdonschot et al. and Schmutz et al., 2015), while restoration had a clear positive effect on richness or diversity of organism groups inhabiting river banks or adjacent shallow shoreline habitats like ground beetles and macrophytes (see Januschke \& Verdonschot as well as Ecke et al., 2015). However, the most floodplain-related organism group (floodplain vegetation) showed no increase in total richness or diversity (see Göthe et al., 2015), in contrast to other studies reporting a significantly higher richness in restored compared to degraded sections (Jähnig et al., 2009; Januschke et al., 2011). These contrasting results were possibly due to the limiting effect of land use, which was much more intense in some of the catchments investigated in REFORM compared to other restoration projects investigated in literature. Currently, the assessment of restoration projects focuses on the biological quality elements as defined by the WFD, i.e. on aquatic organism groups, yet disregarding additional, appropriate indicator groups. This may lead to the wrong conclusion that some restoration measures only achieve little effect. 
Fig. 4 a Overview of the restoration site at the Drau River (Amt der Kärntner LR, Abt.16L; S. Tichy); b Sediment bars and island development due to natural flow dynamics (S. Muhar)

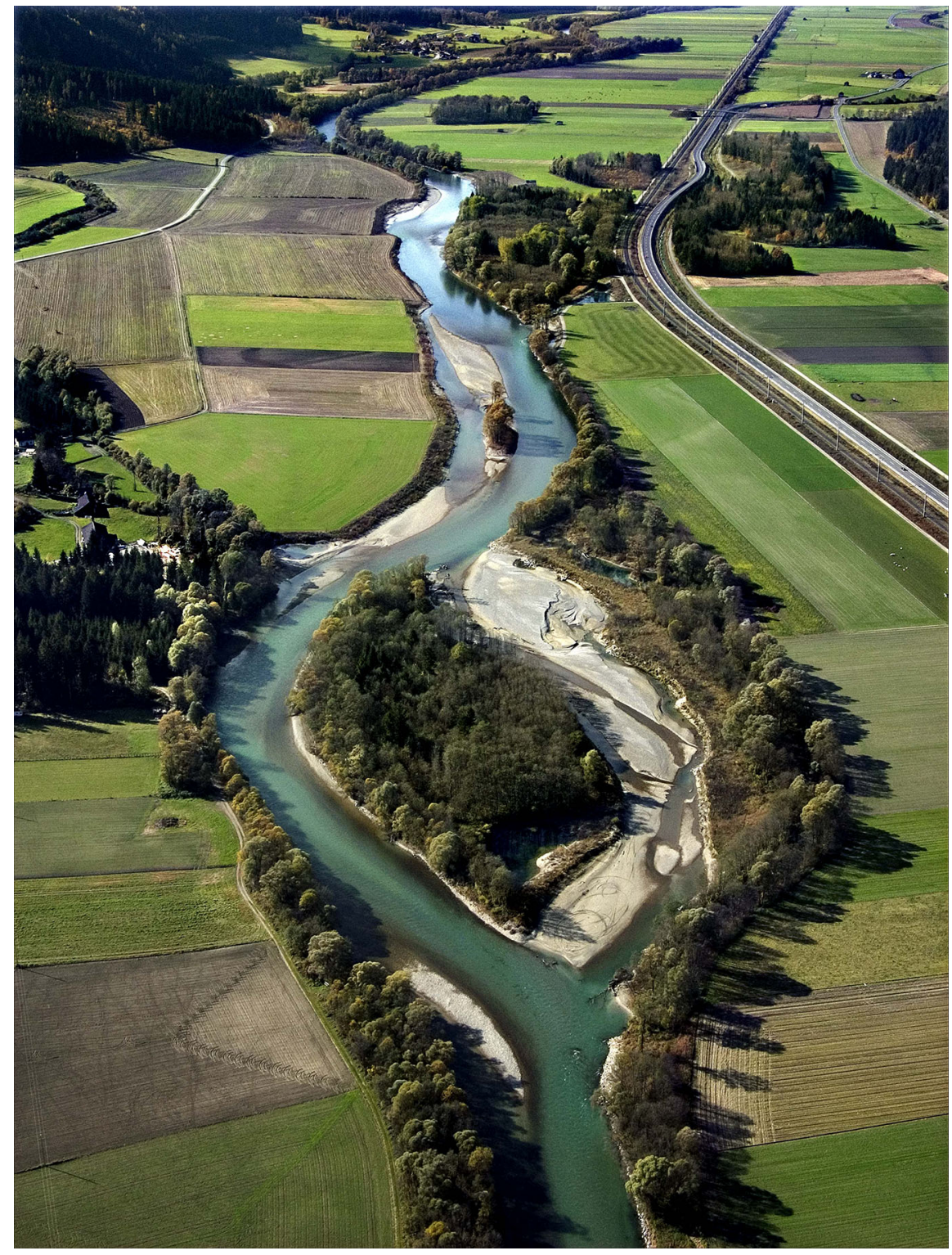

Furthermore, the overall societal benefit should be considered. In eight of the restoration projects investigated in REFORM, the effect of restoration on ecosystem services was quantified, including provisioning (agricultural products, wood, infiltrated drinking water), regulating (flooding, nutrient retention, carbon sequestration) and cultural (recreational hunting and fishing, kayaking, biodiversity conservation, appreciation of scenic landscapes) services. The results show a clear increase of ecosystem services, which was significant over and above considerable variability, and was mainly due to cultural and regulating services (Vermaat et al., 2015). 


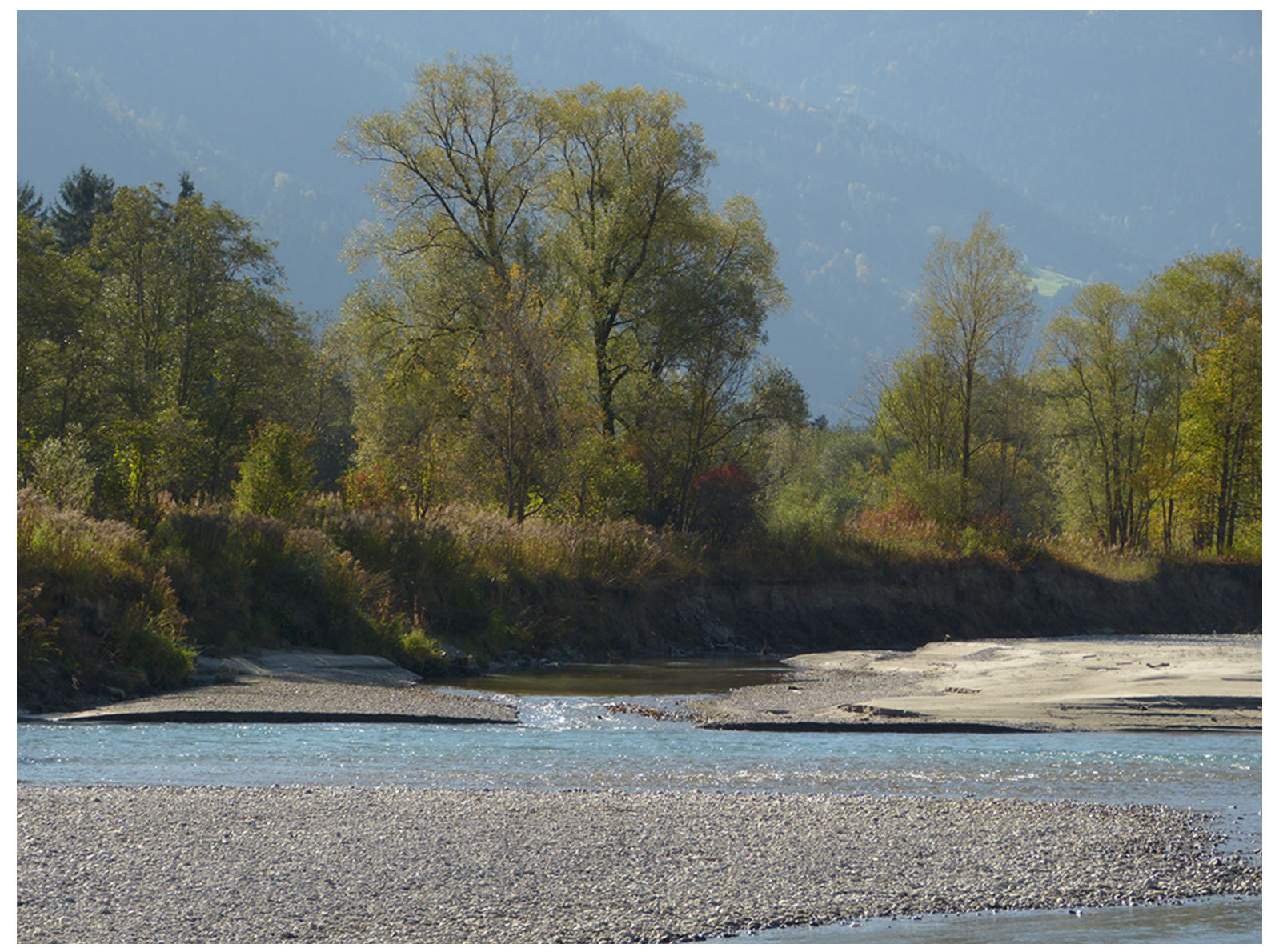

Fig. 4 continued

Fifth, future restoration projects should aim at restoring ecosystem functions and focus more on traits beyond assessing success solely based on species richness and diversity, despite the fact that the latter probably would have higher effects in the obligatory ecological quality ratios of the WFD. In case restoration had a significant effect on species richness or diversity in the 20 restoration projects investigated, it was most pronounced for specific species or traits. For example, (i) ground beetle richness especially increased for species inhabiting sparsely vegetated river banks, (ii) macrophyte richness increased for helophytes - emergent plants rooting under water or in wetted soils but not for other growth forms, and (iii) abundance of small rheophilic fish increased but not for other flow traits (see Januschke and Verdonschot, Ecke et al., Schmutz et al., 2015). Furthermore, organism groups for which overall richness or diversity was not significantly increased showed effects on community structure. For example, (i) the diversity of therophytes and annual floodplain vegetation species increased (see Göthe et al., 2015) and (ii) food source diversity for macroinvertebrates increased as indicated by stable isotopes (see Kupilas et al., 2015). Finally, the communities of the restored and degraded sections were highly dissimilar, also for organism 
Fig. 5 a Overview of the restoration site at the Narew River (Bielenko); b Side branch with dense vegetation succession along the adjacent river corridor (WULS-SGGW)
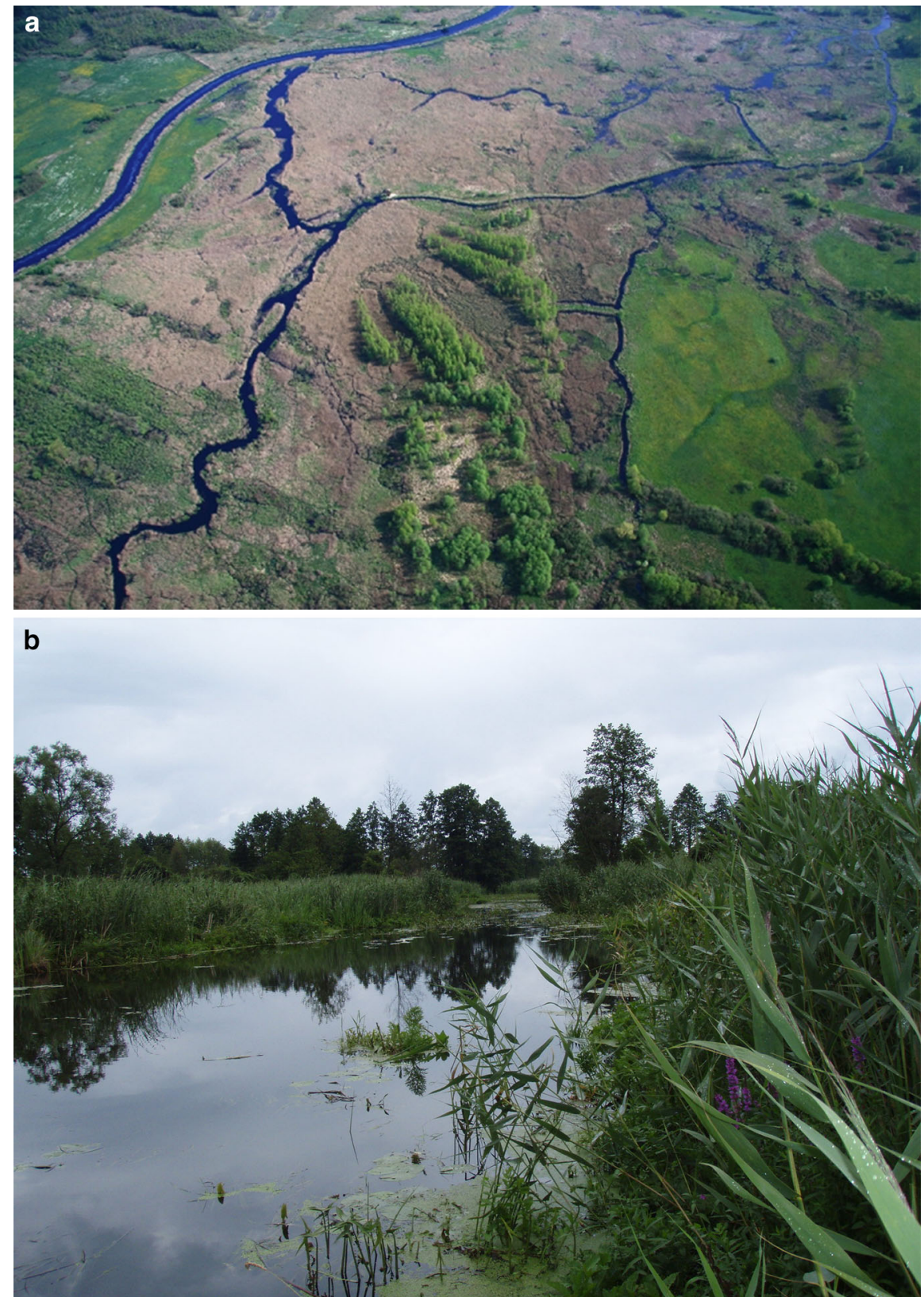

groups which only showed slight changes of the total number of species and diversity (Hering et al., 2015). These results indicate specific functional changes caused by river restoration and can help understand the underlying causal relationships between restoration actions and their hydromorphological and biological effects. A focus on such effects on functions and traits would offer a great opportunity to make fundamental 
Table 3 Length of sampling reaches in dependence of wetted channel width (wcw) and the response variables

\begin{tabular}{lll}
\hline & Reach length $(\mathrm{m})$ for wcw $<50 \mathrm{~m}$ & Reach length $(\mathrm{m})$ for wcw $>50 \mathrm{~m}$ \\
\hline Hymo-survey & $4 \times 100(200)^{*}$ & $4 \times 500$ \\
Hymo-transect method & 200 & 500 \\
Macroinvertebrates & 200 & 200 \\
Fish & $10-20$ times wcw (min. $100 \mathrm{~m})$ & $10-20$ times wcw \\
Macrophytes & 200 & 200 \\
Ground beetles & 200 & 500 \\
Stable isotopes & 200 & 500 \\
Floodplain vegetation & 200 & 500 \\
\hline
\end{tabular}

* wcw $<20 \mathrm{~m}$-length of sampling reach was $100 \mathrm{~m}$; wcw $=20-50 \mathrm{~m}$-length of sampling reach was $200 \mathrm{~m}$, Hymo hydromorphological

Table 4 Sampling area with regard to the response variables

\begin{tabular}{|c|c|c|}
\hline & Recording/sampling area & Recording/sampling season \\
\hline Hymo-survey & $4 \times$ wetted channel width & Low flow in summer \\
\hline $\begin{array}{l}\text { Hymo-transect } \\
\text { method: Channel } \\
\text { features }\end{array}$ & $\begin{array}{l}\text { The floodplain area including aquatic, transient and terrestrial parts; } \\
\text { identification of outer borders of the floodplain by looking for flood } \\
\text { marks, e.g. woody debris stuck in bushes during floods to fix the } \\
\text { sampling area of high water level (wetted channel width).; maximum } \\
\text { width of } 200 \mathrm{~m}\end{array}$ & Low flow in summer \\
\hline $\begin{array}{l}\text { Hymo-transect } \\
\text { method: }\end{array}$ & Aquatic area & Low flow in summer \\
\hline \multicolumn{3}{|l|}{ Microhabitats } \\
\hline Macroinvertebrates & Aquatic area without oxbow lakes & $\begin{array}{l}\text { Low flow in early summer (June } \\
\text { to July) }\end{array}$ \\
\hline Fish & Aquatic area & Late summer/early autumn \\
\hline Macrophytes & Aquatic area & $\begin{array}{l}\text { Maximum growth in low flow } \\
\text { conditions (mid-summer) }\end{array}$ \\
\hline Ground beetles & Strip of the river bank with a maximum width of $10 \mathrm{~m}$ & $\begin{array}{l}\text { Late June (Central European sites) } \\
\text { to early August (Northern } \\
\text { European sites) }\end{array}$ \\
\hline Floodplain vegetation & $\begin{array}{l}\text { The whole flood-prone area including aquatic, transient and terrestrial } \\
\text { parts; in restored sections terrestrial area comprises the bankfull area, } \\
\text { in degraded sections the area of high water level (debris lines); } \\
\text { maximum width of } 200 \mathrm{~m}\end{array}$ & $\begin{array}{l}\text { Maximum growth in low flow } \\
\text { conditions }\end{array}$ \\
\hline Stable isotopes & $\begin{array}{l}\text { Aquatic, transient and terrestrial area; terrestrial area comprises the } \\
\text { whole flood-prone area }+ \text { a strip across the edges of embankment } \\
\text { for sampling of non-riparian beetles }\end{array}$ & Maximum of biomass \\
\hline
\end{tabular}

advances in restoration ecology and to identify (cost)effective restoration measures.

Acknowledgments Funding for this study was provided by the Integrated EU-Project REFORM (REstoring rivers FOR effective catchment Management), European Union's Seventh
Programme for research, technological development and demonstration under Grant Agreement No. 282656. Two anonymous reviewers provided constructive comments for the improvement of this paper. This introductory paper builds in large parts on the research work of the WP 4 team of REFORM; we particularly thank Fraucke Ecke, Emma Göthe, Benjamin Kupilas, Jan Vermaat and Ralf Verdonschot for their helpful 
comments on the manuscript. We would also like to thank Michael Stachowitsch for English proof-reading and Simon Kaufmann, Renate Polt and Kerstin Böck for technical assistance.

Open Access This article is distributed under the terms of the Creative Commons Attribution 4.0 International License (http://creativecommons.org/licenses/by/4.0/), which permits unrestricted use, distribution, and reproduction in any medium, provided you give appropriate credit to the original author(s) and the source, provide a link to the Creative Commons license, and indicate if changes were made.

\section{References}

Ecke, F., S. Hellsten, J. Köhler, A. Lorenz, J. Rääpysjärvi, S. Scheunig, J. Segersten \& A. Baattrup-Pedersen, 2015. The response of hydrophyte growth forms and plant strategies to river restoration. Hydrobiologia. doi:10.1007/s10750015-2605-6.

Fausch, K. D. \& T. G. Northcote, 1992. Large woody debris and salmonid habitat in a small coastal British Columbia stream. Canadian Journal of Fisheries and Aquatic Science 49: 682-693.

Göthe, E., A. Timmerman, K. Januschke, D. Hering \& A. Baattrup-Pedersen, 2015. Structural and functional responses of floodplain vegetation to stream ecosystem restoration. Hydrobiologia. doi:10.1007/s10750-015-2401-3.

Haase, P., D. Hering, S. C. Jähnig, A. W. Lorenz \& A. Sundermann, 2013. The impact of hydromorphological restoration on river ecological status: a comparison of fish, benthic invertebrates and macrophytes. Hydrobiologia 704: 475-488.

Hering, D., J. Aroviita, A. Baattrup-Pedersen, K. Brabec, T. Buijse, F. Ecke, N. Friberg, M. Gielczewski, K. Januschke, J. Köhler, B. Kupilas, A. Lorenz, S. Muhar, A. Paillex, M. Poppe, T. Schmidt, S. Schmutz, J. Vermaat, P. Verdonschot \& R. Verdonschot, 2015. Contrasting the roles of section length and instream habitat enhancement for river restoration success: A field study on 20 European restoration projects. Journal of Applied Ecology 52: 1518-1527.

Jähnig, S. C., S. Brunzel, S. Gacek, A. W. Lorenz \& D. Hering, 2009. Effects of re-braiding measures on hydromorphology, floodplain vegetation, ground beetles and benthic invertebrates in mountain rivers. Journal of Applied Ecology 46: 406-416.

Jähnig, S. C., K. Brabec, A. Buffagni, S. Erba, A. W. Lorenz, T. Ofenböck, P. F. M. Verdonschot \& D. Hering, 2010. A comparative analysis of restoration measures and their effects on hydromorphology and benthic invertebrates in 26 central and southern European rivers. Journal of Applied Ecology 47: 671-680.

Januschke, K. \& R. Verdonschot, 2015. Effects of river restoration on riparian ground beetles (Coleoptera: Carabidae) in Europe. Hydrobiologia. doi:10.1007/s10750-0152532-6.

Januschke, K., A. Sundermann, C. Antons, P. Haase, A. W. Lorenz \& D. Hering, 2009. Untersuchung und Auswertung von ausgewählten Renaturierungsbeispielen repräsentativer Fließgewässertypen der Flusseinzugsgebiete
Deutschlands. Verbesserung der biologischen Vielfalt in Fließgewässern und ihren Auen. Schriftenreihe des Deutschen Rates für Landespflege 82: 23-39.

Januschke, K., S. Brunzel, P. Haase \& D. Hering, 2011. Effects of stream restorations on riparian mesohabitats, vegetation and carabid beetles: a synopsis of 24 cases from Germany. Biodiversity and Conservation 20: 3147-3164.

Januschke, K., S. C. Jähnig, A. W. Lorenz \& D. Hering, 2014. Mountain river restoration measures and their success(ion): effects on river morphology, local species pool, and functional composition of three organism groups. Ecological Indicators 38: 243-255.

Kail, J. \& D. Hering, 2009. The influence of adjacent stream reaches on the local ecological status of Central European mountain streams. River Research and Applications 25: 537-550.

Kail, J., K. Brabec, M. Poppe \& K. Januschke, 2015. The effect of river restoration on fish, macroinvertebrates and macrophytes: a meta-analysis. Ecological Indicators 58: 311-321.

Kiffney, P. M., J. S. Richardson \& J. P. Bull, 2003. Responses of periphyton and insects to experimental manipulation of riparian buffer width along forest streams. Journal of Applied Ecology 40: 1060-1076.

Kupilas, B., N. Friberg, B. G. McKie, M. A. Jochmann, A. W. Lorenz \& D. Hering, 2015. River restoration and the trophic complexity of benthic invertebrate communities across 16 European restoration projects. Hydrobiologia. doi:10.1007/s10750-015-2569-6.

Lepori, F., D. Palm, E. Brannas \& B. Malmqvist, 2005. Does restoration of structural heterogeneity in streams enhance fish and macroinvertebrate diversity? Ecological Applications 15: 2060-2071.

Lorenz, A. W. \& C. K. Feld, 2013. Upstream river morphology and riparian land use overrule local restoration effects on ecological status assessment. Hydrobiologia 704: 489-501.

Lorenz, A. W., T. Korte, A. Sundermann, K. Januschke \& P. Haase, 2012. Macrophytes respond to reach-scale river restorations. Journal of Applied Ecology 49: 202-212.

Mandler, H., W. Petutschnig \& N. Sereinig, 2004. LIFE-Projekt Auenverbund Obere Drau. Endbericht, Amt der Kärnter Landesregierung, Klagenfurt.

Marzin, A., P. F. M. Verdonschot \& D. Pont, 2013. The relative influence of catchment, riparian corridor, and reach-scale anthropogenic pressures on fish and macroinvertebrate assemblages in French rivers. Hydrobiologia 704: 375-388.

Miller, S. W., P. Budy \& J. C. Schmidt, 2010. Quantifying macroinvertebrate responses to in-stream habitat restoration: applications of meta-analysis to river restoration. Restoration Ecology 18: 8-19.

Muhar, S., M. Jungwirth, G. Unfer, C. Wiesner, M. Poppe, S. Schmutz, S. Hohensinner \& H. Habersack, 2007. Restoring riverine landscapes at the Drau River: successes and deficits in the context of ecological integrity. Developments in Earth Surface Processes 2025: 779-803.

Nilsson, C., L. E. Povi, J. Gardeström, E. M. Hasselquist, L. Lind \& J. M. Sarneel, 2015. Riparian and in-stream restoration of boreal streams and rivers: success or failure? Ecohydrology 5: 753-764.

Osenberg, C. W., O. Sarnelle \& S. D. Cooper, 1997. Effect size in ecological experiments: the application of biological models in meta-analysis. The American Naturalist 150: 798-812. 
Palmer, M. A., H. Menninger \& E. S. Bernhardt, 2010. River restoration, habitat heterogeneity and biodiversity: a failure of theory or practice? Freshwater Biology 55: 205-222.

Poppe, M., J. Kail, J. Aroviita, M. Stelmaszczyk, M. Giełczewski \& S. Muhar, 2015. Assessing restoration effects on hydromorphology in European mid-sized rivers by key hydromorphological parameters. Hydrobiologia. doi:10. 1007/s10750-015-2468-x.

Richards, K., J. Brasington \& F. Hughes, 2002. Geomorphic dynamics of floodplains: ecological implications and a potential modelling strategy. Freshwater Biology 47: 559-579.

Roni, P., K. Hanson \& T. Beechie, 2008. Global review of the physical and biological effectiveness of stream habitat rehabilitation techniques. North American Journal of Fisheries Management 28: 856-890.

Schmutz, S., H. Kremser, A. Melcher, M. Jungwirth, S. Muhar, H. Waidbacher \& G. Zauner, 2014. Ecological effects of rehabilitation measures at the Austrian Danube: a metaanalysis of fish assemblages. Hydrobiologia 729: 49-60.

Schmutz, S., P. Jurajda, S. Kaufmann, A. Lorenz, S. Muhar, A. Paillex, M. Poppe \& C. Wolter, 2015. Response of fish assemblages to hydromorphological restoration in central and northern European rivers. Hydrobiologia. doi:10.1007/ s10750-015-2354-6.

Stoll, S., J. Kail, A. W. Lorenz, A. Sundermann \& P. Haase, 2014. The importance of the regional species pool, ecological species traits and local habitat conditions for the colonization of restored river reaches by fish. PLoS ONE 9: e84741.
Sundermann, A., M. Gerhardt, H. Kappes \& P. Haase, 2013. Stressor prioritisation in riverine ecosystems: which environmental factors shape benthic invertebrate assemblage metrics? Ecological Indicators 27: 83-96.

Tonkin, J. D., S. Stoll, A. Sundermann \& P. Haase, 2014. Dispersal distance and the pool of taxa, but not barriers, determine the colonisation of restored river reaches by benthic invertebrates. Freshwater Biology 59: 1843-1855.

Verdonschot, R., J. Kail, B. G. McKie \& P. F. M. Verdonschot, 2015. The role of benthic microhabitats in determining the effects of hydromorphological river restoration on macroinvertebrates. Hydrobiologia. doi:10.1007/s10750015-2575-8.

Vermaat, J., A. J. Wagtendonk, R. Brouwer, O. Sheremet, A. Erik, T. Brockhoff, M. Plug, S. Hellsten, J. Aroviita, L. Tylec, M. Gielczewski, L. Kohut, K. Brabec, J. Haverkamp, M. Poppe, K. Boeck, M. Coerssen, J. Segersten \& D. Hering, 2015. Assessing the societal benefits of river restoration using the ecosystem services approach. Hydrobiologia. doi:10.1007/s10750-015-2482-z.

Wahl, C. M., A. Neils \& D. Hooper, 2013. Impacts of land use at the catchment scale constrain the habitat benefits of stream riparian buffers. Freshwater Biology 58: 2310-2324.

Water Framework (WF-D) Directive 2000/60/EC of the European Parliament and of the Council of 23 October 2000 establishing a framework for community action in the field of water policy. 